\title{
Cell biology of mechanotransduction in inner-ear hair cells David P Corey
}

\author{
Address: Howard Hughes Medical Institute, Department of Neurobiology, Harvard Medical School, 220 Longwood Avenue, \\ Boston, MA 02115, USA \\ Email: dcorey@hms.harvard.edu
}

Fl000 Biology Reports 2009, I:58 (doi:I0.34I0/BI-58)

The electronic version of this article is the complete one and can be found at: http://FI000.com/Reports/Biology/content/I/58

\begin{abstract}
The cloning of deafness genes, especially those for Usher syndrome, has helped to identify a variety of structural proteins involved in the development and function of hair-cell stereocilia. These include novel cadherins, a handful of myosin motors, and scaffolding proteins. Yet a new understanding of these proteins has upended the orthodox view of mechanosensation by hair cells.
\end{abstract}

\section{Introduction and context}

Ten years ago, we had a pretty good idea of how mechanotransduction in inner-ear hair cells worked: from the top of each hair cell emanates a bundle of actincored stereocilia (Figure 1a), and deflection of the bundle toward the taller stereocilia opens ion channels to depolarize the cell. This happens, it was thought, because fine 'tip links' extending between stereocilia (Figure 1b) were stretched by the relative shear of adjacent stereocilia (Figure 1c); the resulting tension pulled open force-gated transduction channels situated at each end of each tip link. In addition, the hair cell used motor complexes located at the upper end of each tip link to continuously adjust the resting bias on these channels, thereby producing an adaptation to static stimuli (reviewed in [1]). This motor was composed of myosin-1c molecules that were regulated by $\mathrm{Ca}^{2+}$ entering through nearby transduction channels [2].

Five years ago, we knew even more: the tip link had been tentatively identified as cadherin 23 [3], the adaptation motor had been confirmed as myosin $1 \mathrm{c}$ by a chemical genetic strategy [4], and a strong candidate for the transduction channel itself, TRPA1 (transient-receptorpotential-like, ankyrin-containing ion channel 1), had been found [5]. It seemed there were just a few details to work out, and these had to do with how the motor, tip link, and channel were all connected. However, a flurry of new papers has shaken this view of hair-cell transduction in several fundamental ways.

\section{Major recent advances}

First, it was found that TRPA1 is not an essential component of the transduction apparatus. TRPA1 is made by hair cells and does play an important regulatory role in the cochlea, but mechanotransduction itself is perfectly normal in mice lacking TRPA1 [6]. At the moment, there are no other good channel candidates stepping forward for consideration. Second, the tip link turned out to be more complex than imagined. A combination of exquisite immunogold and negative stain electron microscopy [7] showed that the tip link is most likely a tetramer of cadherins: two parallel strands of cadherin 23 forming the upper two-thirds of the link and two parallel strands of protocadherin 15 forming the lower one-third (Figure 1d). This structure helps in understanding inherited hearing loss in that cadherin 23 and protocadherin 15 are both products of genes defective in the human Usher syndrome, a disorder characterized by congenital deafness and progressive blindness (Usher types 1D and 1F, respectively).

However, the structure appears incompatible with earlier views of the transduction apparatus, in which the tip link acts as an elastic spring. First, the extracellular portions of these cadherins do not appear very stretchy in electron micrographs. Second, steered molecular dynamics simulations of cadherins [8] predict an elasticity much lower than that known from biophysical measurements to be associated with the transduction apparatus. There are now speculations about where that springiness might be 
Figure I. Mechanotransduction in vertebrate hair cells
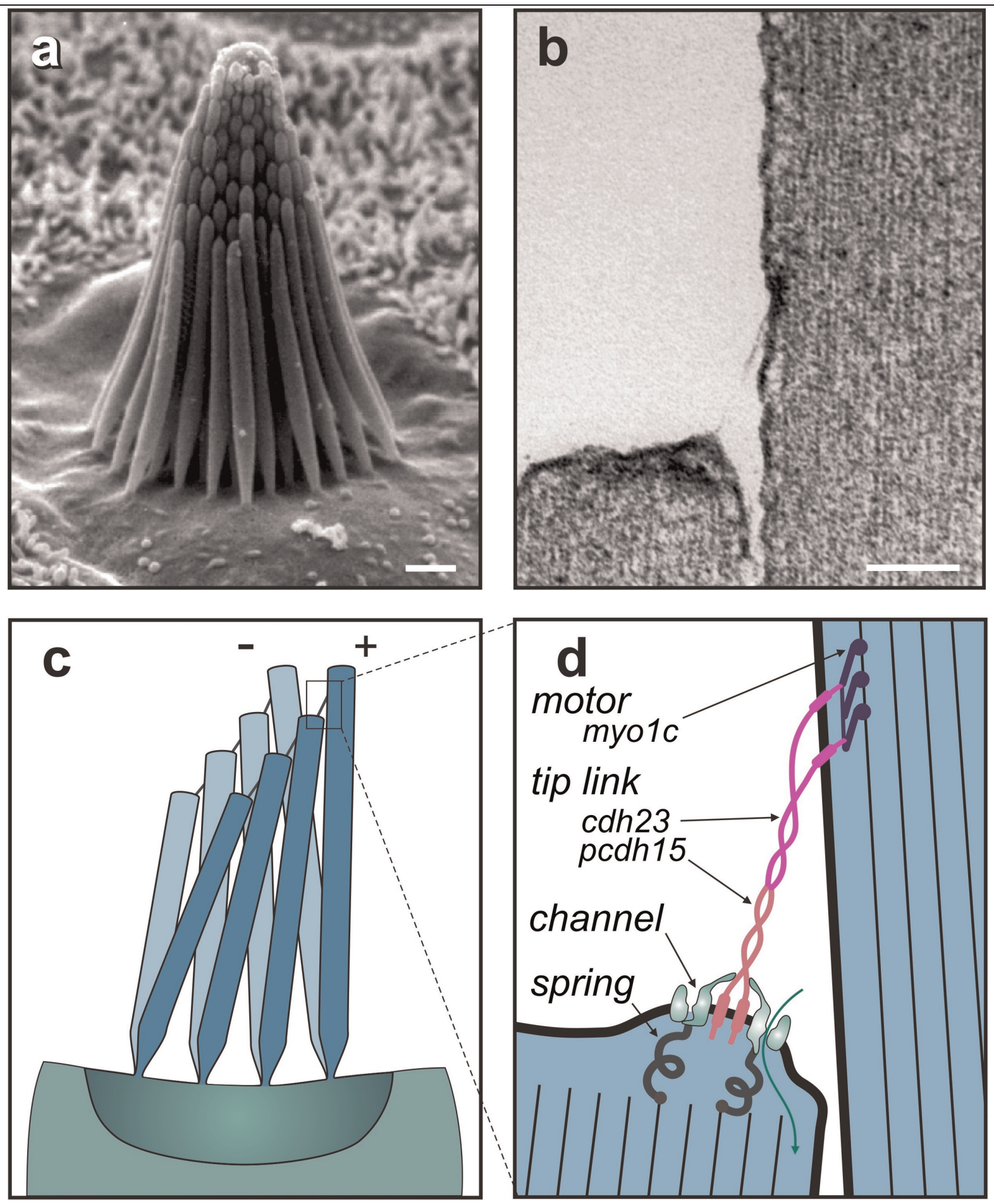

(a) The hair bundle of each hair cell shows a graded increase in stereocilia heights (scale $=1 \mu \mathrm{m}$ ). Deflections toward the tallest stereocilia are excitatory, opening transduction channels near their tips. (b) A $170 \mathrm{~nm}$ tip link, composed of cadherin 23 and protocadherin 15, extends along the sensitive axis from the tip of each stereocilium to the side of its tallest neighbor (scale $=100 \mathrm{~nm}$ ). (c) When deflected, stereocilia remain touching at their tips but shear, so that excitatory deflections act to tighten tip links. (d) A revised model for transduction supposes that ion channels at the lower end of each tip link are pulled open by tip-link tension. Tip links are attached to the actin cores of stereocilia by myosin-Ic motor proteins at their upper ends and through mechanosensitive transduction channels at their lower ends. cdh23, cadherin 23; myolc, myosin Ic; pcdh I5, protocadherin I5. 
[9]; for instance, there may be elastic proteins attaching the transduction channels to the actin cores of stereocilia (Figure 1d), but they have not been identified. Molecular dynamics simulations also provided greater understanding of Usher syndrome as they showed that mutations in the extracellular domains that produce hearing loss reduce the unfolding strength of the cadherin filament by half or more [10].

The asymmetry of the tip link is also problematic. Earlier $\mathrm{Ca}^{2+}$ imaging of vestibular hair cells had suggested that transduction channels were located at both ends of the tip link. This now seems less likely if the tip link has different cadherins at its two ends. More recently, the $\mathrm{Ca}^{2+}$ imaging was revisited with cochlear hair cells and faster methods; these experiments found no $\mathrm{Ca}^{2+}$ entry and thus no channels - at the upper ends of tip links [11]. The most likely arrangement at present is exactly two transduction channels per tip link, both at the lower end (Figure 1d). It would make sense for the mechanics of channel gating if each channel were independently tethered by a cytoplasmic elastic protein to the actin core and if each channel were attached to one protocadherin 15 strand, perhaps by an extracellular domain of the channel protein (Figure 1d).

Nevertheless, this new view has problems. Myosin 1c, the motor that regulates tip-link tension and thereby mediates adaptation, has a rate controlled by $\mathrm{Ca}^{2+}$. It is also well established that most or all of this $\mathrm{Ca}^{2+}$ enters through transduction channels. Yet if the myosin $1 \mathrm{c}$ is at the upper end of the tip link and the channels are at the lower end, there is no simple way for $\mathrm{Ca}^{2+}$ to reach the myosin. A partial solution is that $\mathrm{Ca}^{2+}$ entering through transduction channels could reach the myosin $1 \mathrm{c}$ for the next lower tip link, less than a micrometer away, but how the motors are regulated for the tallest stereocilium of each column, which has no channels, remains a mystery.

The discovery of Usher syndrome proteins has helped elucidate other components of the sensory hair bundle. The genes for Usher types 1B, 1C, and 1G encode myosin $7 \mathrm{a}$, harmonin, and sans, respectively. Many or all of these proteins form a complex with cadherin 23 and protocadherin 15 (reviewed in [12]), with harmonin and sans serving as scaffolding proteins and myosin $7 \mathrm{a}$ perhaps involved in carrying the complex to the tips of stereocilia.

Still other Usher syndrome proteins may be involved in holding the stereocilia together. Usherin and VLGR1 (very large G-protein-coupled receptor 1), encoded by the genes defective in Usher $2 \mathrm{~A}$ and $2 \mathrm{C}$, respectively, are transmembrane proteins with very large extracellular domains. Both are thought to be associated with the ankle links, extensive ropy filaments connecting adjacent stereocilia near where they taper at their bases $[13,14]$. It is clear that something tightly links adjacent stereocilia; if just a few stereocilia of a bundle are pulled by a stimulus probe, all of them move together. Stereocilia were observed to move coherently at frequencies of tens of kilohertz [15], and they do not separate by more than a few nanometers, even when the bundle is deflected by 1,000 nanometers [16]. The mechanism of this sliding adhesion remains obscure. However, it is not mediated by the ankle links, which can be removed enzymatically without causing bundles to splay apart, nor by tip links, which can be similarly cut without affecting cohesion. A third set of links, situated just below the tip links and known as horizontal top connectors, may be responsible, but they have not been identified and the mechanism of sliding adhesion without separation has not been elucidated.

The discovery of yet other deafness genes has helped reveal how the heights of stereocilia are regulated during development to produce the stereotyped staircase of heights. The gene defective in Usher 2D encodes whirlin, a scaffolding protein, and the gene defective in a human non-syndromic recessive deafness, DFNB3, encodes the motor protein myosin 15 . Both are located at the tips of stereocilia, they interact directly, and both are needed for stereocilia elongation $[17,18]$. But recent work shows that another myosin and its cargo are also involved: the gene defective in DFNB30 encodes myosin 3a, which binds the actin-bundling protein espin 1, a product of the gene defective in DFNB36. Myosin 3a transports espin 1 to the tips of actin filaments, and overexpression of both in hair cells promotes elongation of stereocilia $[19,20]$.

\section{Future directions}

Key issues remain unresolved. The localization of ion channels only at the lower end of each tip link (Figure 1d) must be confirmed in other hair-cell organs. Much work remains in figuring out how $\mathrm{Ca}^{2+}$ entry through those channels controls adaptation, whether by binding to the myosin 1c motor or to the channels or both. There is some understanding of how the various Usher gene products myosin $7 \mathrm{a}$, harmonin, sans, cadherin 23 , and protocadherin 15 - are connected to each other, but we need much more detailed information on these linkages and how they assemble in the first place. Sliding adhesion remains a significant mystery; it is particularly important for hair cells but may function similarly in other tissues as well. We must understand how myosin 15 and myosin $3 a$, and their cargos whirlin and espin 1, interact with each other and with unidentified proteins to create the exquisite 
shape of the hair bundle. Finally, few of these proteins are expressed solely in hair cells. To what extent do they perform similar roles in mechanosensation and cellular mechanics in other tissues?

\section{Abbreviations}

DFNB, human non-syndromic recessive deafness; TRPA1, transient-receptor-potential-like, ankyrin-containing ion channel 1; VLGR1, very large G-proteincoupled receptor 1.

\section{Competing interests}

The author declares that he has no competing interests.

\section{Acknowledgements}

Work in the author's laboratory is supported by the Howard Hughes Medical Institute and by the National Institute of Deafness and other Communication Disorders (NIDCD), one of the National Institutes of Health (NIH).

\section{References}

I. Sukharev S, Corey DP: Mechanosensitive channels: multiplicity of families and gating paradigms. Sci STKE 2004, 2004:re4.

2. Garcia JA, Yee AG, Gillespie PG, Corey DP: Localization of myosin-lbeta near both ends of tip links in frog saccular hair cells. J Neurosci 1998, 18:8637-47.

3. Siemens J, Lillo C, Dumont RA, Reynolds A, Williams DS, Gillespie PG, Muller U: Cadherin 23 is a component of the tip link in hair-cell stereocilia. Nature 2004, 428:950-5.

FI000 Factor 7.0 Must Read

Evaluated by Karen P Steel 13 Apr 2004, Ellen A Lumpkin 15 Apr 2004, David P Corey 19 Apr 2004, Geoffrey A Manley 04 May 2004, John Ngai 17 May 2004, Jaime García-Añoveros 18 Aug 2004

4. Holt JR, Gillespie SK, Provance DW, Shah K, Shokat KM, Corey DP, Mercer JA, Gillespie PG: A chemical-genetic strategy implicates myosin-Ic in adaptation by hair cells. Cell 2002, I08:37I-8I.

FI000 Factor 8.0 Exceptional

Evaluated by Guy Richardson 26 Feb 2002, Ellen A Lumpkin 27 May 2002

5. Corey DP, Garcia-Anoveros J, Holt JR, Kwan KY, Lin SY, Vollrath MA, Amalfitano A, Cheung EL, Derfler BH, Duggan A, Geleoc GS, Gray PA, Hoffman MP, Rehm HL, Tamasauskas D, Zhang DS: TRPAI is a candidate for the mechanosensitive transduction channel of vertebrate hair cells. Nature 2004, 432:723-30.

FI000 Factor II.0 Exceptional

Evaluated by Roger Hardie 18 Oct 2004, Karen P Steel 19 Oct 2004, Guy Richardson 21 Oct 2004. Ardem Patapoutian 27 Oct 2004, Peter Gillespie 05 Nov 2004, Dora Angelaki 08 Nov 2004, Ellen A Lumpkin 18 Nov 2004, Venkatesh Murthy 03 Dec 2004

6. Kwan KY, Allchorne AJ, Vollrath MA, Christensen AP, Zhang DS, Woolf CJ, Corey DP: TRPAI contributes to cold, mechanical, and chemical nociception but is not essential for hair-cell transduction. Neuron 2006, 50:277-89.

FI000 Factor 6.4 Must Read

Evaluated by Paul Garrity 03 May 2006, Jaime García-Añoveros 03 May 2006
7. Kazmierczak P, Sakaguchi H, Tokita J, Wilson-Kubalek EM, Milligan RA, Muller U, Kachar B: Cadherin 23 and protocadherin I5 interact to form tip-link filaments in sensory hair cells. Nature 2007, 449:87-91.

FI000 Factor 8.0 Must Read

Evaluated by Guy Richardson 05 Oct 2007, Peter Gillespie 08 Oct 2007

8. Sotomayor M, Corey DP, Schulten K: In search of the hair-cell gating spring: Elastic properties of ankyrin and cadherin repeats. Structure (Camb) 2005, I 3:669-82.

9. Kachar B, Parakkal M, Kurc M, Zhao Y, Gillespie PG: Highresolution structure of hair-cell tip links. Proc Natl Acad Sci U S A 2000, 97:|3336-4|.

10. Sotomayor M, Schulten $\mathrm{K}$ : The allosteric role of the $\mathrm{Ca}^{2+}$ switch in adhesion and elasticity of C-cadherin. Biophys J 2008, 94:462I-33.

II. Beurg M, Fettiplace R, Nam JH, Ricci AJ: Localization of inner hair cell mechanotransducer channels using high-speed calcium imaging. Nat Neurosci 2009, I 2:553-8.

FI000 Factor 6.0 Must Read

Evaluated by Geoffrey A Manley 09 Apr 2009

12. El-Amraoui A, Petit C: Usher I syndrome: unravelling the mechanisms that underlie the cohesion of the growing hair bundle in inner ear sensory cells. J Cell Sci 2005, I 1 8:4593-603.

13. Adato A, Lefevre G, Delprat B, Michel V, Michalski N, Chardenoux S, Weil D, El-Amraoui A, Petit C: Usherin, the defective protein in Usher syndrome type IIA, is likely to be a component of interstereocilia ankle links in the inner ear sensory cells. Hum Mol Genet 2005, 14:3921-32.

14. McGee J, Goodyear RJ, McMillan DR, Stauffer EA, Holt JR, Locke KG, Birch DG, Legan PK, White PC, Walsh EJ, Richardson GP: The very large G-protein-coupled receptor VLGRI: a component of the ankle link complex required for the normal development of auditory hair bundles. J Neurosci 2006, 26:6543-53.

FI000 Factor 3.0 Recommended Evaluated by Peter Gillespie 05 Jul 2006

15. Kozlov AS, Risler T, Hudspeth AJ: Coherent motion of stereocilia assures the concerted gating of hair-cell transduction channels. Nat Neurosci 2007, 10:87-92.

16. Karavitaki KD, Corey DP: Hair bundle mechanics at high frequencies: a test of series or parallel transduction. In Auditory Mechanisms: Processes and Models. Edited by Nuttall AL, Ren T, Gillespie PG, Grosh K, de Boer E, Hackensack, NJ: World Scientific Publishing Co; 2005:286-92.

17. Belyantseva IA, Boger ET, Naz S, Frolenkov GI, Sellers JR, Ahmed ZM, Griffith AJ, Friedman TB: Myosin-XVa is required for tip localization of whirlin and differential elongation of hair-cell stereocilia. Nat Cell Biol 2005, 7:148-56.

18. Delprat B, Michel V, Goodyear R, Yamasaki Y, Michalski N, ElAmraoui A, Perfettini I, Legrain P, Richardson G, Hardelin JP, Petit C: Myosin XVa and whirlin, two deafness gene products required for hair bundle growth, are located at the stereocilia tips and interact directly. Hum Mol Genet 2005, I 4:40I-I0.

19. Schneider ME, Dose AC, Salles FT, Chang W, Erickson FL, Burnside B, Kachar B: A new compartment at stereocilia tips defined by spatial and temporal patterns of myosin Illa expression. J Neurosci 2006, 26:10243-52.

FI000 Factor 3.0 Recommended Evaluated by Peter Gillespie 02 Nov 2006

20. Salles FT, Merritt RC Jr, Manor U, Dougherty GW, Sousa AD, Moore JE, Yengo CM, Dose AC, Kachar B: Myosin IIla boosts elongation of stereocilia by transporting espin I to the plus ends of actin filaments. Nat Cell Biol 2009, I I:443-50. 